\title{
Progressive and Prognosis Role of Lipogenic Pathway in Hepatocellular Carcinoma: A Systematic Review and Meta-Analysis
}

\author{
REHAB M. SAMAKA, M.D.*; MOHAMMAD I. SHABAN, M.D.*; MERVAT M. SULTAN, M.D.**; \\ SHEREEN F. EL-GODAY, M.D.* and DINA M. SWEED, M.Sc.** \\ The Department of Pathology, Faculty of Medicine* and National Liver Institute**, Menoufia University, Shebin El-Kom, Egypt
}

\begin{abstract}
Background and Aims: Despite the advance in treatment modalities, Hepatocellular Carcinoma (HCC) remains a common cause of cancer morbidity and mortality worldwide. Lipogenic pathway is expected to become a potential therapeutic target for prevention and treatment of HCC.
\end{abstract}

Aim of Study: Studying the role of lipogenic pathway in hepatocellular carcinoma.

Material and Methods: We searched the PubMed and Google scholar databases for relevant studies that evaluated the expression of lipogenic pathway markers; Sterol Regulatory Element-binding Protein1 (SREBP1), Fatty Acid Synthase (FASN) and Stearoyl-CoA Desaturase1 (SCD1) in human HCC tissues.

Results: This review included 12 studies that enrolled 1031 patients with HCC or chronic hepatitis and normal subjects. SREBP1, FASN and SCD1 were overexpressed in HCC. SREBP1 expression was positively correlated with FASN and SCD expressions $(r=0.74, p<0.001$ and $r=0.82, p$ $<0.001$, respectively). Overexpression of SREBP1 and SCD1 was associated with poor clinico-pathological data and poor Overall Survival (OS) $(\mathrm{HR}=23.09 ; 95 \% \mathrm{CI}=1.21-438.67 ; p$ $=0.04)$ and $(\mathrm{HR}=6.82 ; 95 \% \mathrm{CI}=3.53-13.16 ; p<0.001)$, respectively.

Conclusion: We concluded that lipogenic pathway activation plays an important role in HCC development and prognosis. This review was registered with PROSPERO (CRD 42018087933).

Key Words: FASN-HCC - Lipogenic pathway - SCD1SREBP1.

\section{Introduction}

LIVER cancer is a lethal cancer with rising incidence rate in different parts of the world [1]. In developing countries, Hepatocellular Carcinoma (HCC) is the second leading cause of cancer death in male, while its rank is the sixth in developed

Correspondence to: Dr. Dina M. Sweed, E-Mail: dr.dinasweed@yahoo.com countries [2]. Risk factors for $\mathrm{HCC}$ include hepatitis $\mathrm{B}(\mathrm{HBV})$, hepatitis $\mathrm{C}(\mathrm{HCV})$, alcohol consumption, and non-alcoholic fatty liver disease and metabolic causes [3]. Despite advances in HCC treatment, only one third of these patients will benefit from these treatment modalities [4]. This could be attributed to difficultly in early detection and diagnosis of HCC. Therefore, most patients are presented at advanced clinical stage with poor outcome [5] Moreover, no single chemotherapeutic agent or combination of agents has led to a significant increase in overall survival in advanced $\mathrm{HCC}$ cases [6]. So, identification of key drivers and mediators of HCC remains the hallmark for successful drug development.

De novo lipogenesis is one of the most important metabolic hallmarks of cancer development and enhance tumor cell survival [7]. It is regulated by a family of transcription factors known as Sterol Regulatory Element-Binding Proteins (SREBPs) [8]. SREBPs are composed of three isoforms: SREBP1a, SREBP1c and SRBEP2 and are encoded by two sterol regulatory element binding transcription factor genes; SREBF1 and SREBF2 [9]. SREBPs are present in a complex form within the Endoplasmic Reticulum (ER) membrane. Upon activation, they undergo proteolytic cleavage with translocation of the mature $\mathrm{N}$-terminus into the nucleus [10]. This leads to activation of downstream target genes such as Fatty Acid Synthase (FASN) and stearoyl-CoA desaturase1 (SCD1).

SREBP1 overexpression has been reported in a variety of human cancer including prostate and endometrial cancer and acts as an independent prognostic marker in breast and pancreatic cancers [11-14]. Similarly, studies from different tumor types including breast and ovarian cancers show that high expression of FASN is associated with tumor 
progression and poor survival $[\mathbf{1 5 , 1 6 ]}$. Also, high expression of SCD1 has been observed in different human cancers and its overexpression predicts a poor patient outcome $[\mathbf{1 7 , 1 8 ]}$. Interestingly, several studies show that therapeutic targeting of different proteins involved in the activation of lipogenic pathway such as SREBP1, FASN and SCD1 may result in tumor regression [12,19-21].

We focus in this systematic review and metaanalyses on observing the expression levels of SREBP1, FASN and SCD1 in HCC tissue, adjacent non-tumor tissue and normal control tissue. Also, we will analyze the correlation between overexpression of these markers in HCC tissue with respect to available clinico-pathological features and patients' survival data. This could provide new guidelines for early diagnosis, evaluate prognosis and establish a personalized treatment regimen of HCC.

\section{Material and Methods}

This review was established using a prospective protocol. It was performed according to the Preferred Reporting Items for Systematic Reviews and Meta-analyses (PRISMA) statement [22]. The project was registered with the PROSPERO database, number CRD 42018087933.

\section{Eligibility criteria:}

We evaluated all studies that assessed expression of SREBP1, FASN and SCD1 in human HCC and non-HCC tissue. We also included studies compared their expressions in association with the clinicopathological features and patients' outcome. We did not restrict the search by date or publication status. During February 2018, we searched PubMed and Google Scholar using the MeSH terms "hepatocellular carcinoma" and "lipogenic pathway, SREBP1, SCD1, FASN, fatty acid synthetase, sterol regulatory binding protein 1 and steroayl-coenzyme A desaturase1". We also browsed reference lists. Different methods of assessment were included, where Immunohistochemistry (IHC) was performed in eleven studies, quantitative real time-polymerase chain reaction (qRT-PCR) was reported in eight studies. Finally, microarray platform and SCD gene expression from 325 patients of $\mathrm{HCC}$ was also included in which data was obtained from two independent patient cohort studies [Liver Cancer Institute (LCI) and Laboratory of Experimental Carcinogenesis (LEC)].

\section{Selection of studies and data extraction:}

Two authors independently checked the abstracts and full-texts to assess the eligibility of the articles found in the literature search. Any disagreements were resolved by discussion with a third author. Study characteristics, such as the gender, sample size, tumor stage, histological grade, cirrhosis, $\mathrm{HBV} / \mathrm{HCV}(\%)$, method of detection, target and follow-up were recorded. We assessed the difference of markers expression between HCC and non-tumor liver tissue as the primary outcome. We also explored the association between markers expression and adverse clinicopathological data, OS and DFS as the secondary outcome.

\section{Dealing with missing data:}

We used RevMan Calculator created by Drahota, Amy and Beller Elainen for calculating Standard Deviation (SD) of mean change from baseline.

\section{Risk of bias assessment:}

Two authors independently used NewcastleOttawa Scale (NOS) for assessing the risk of bias in each study included in this review [23].

\section{Data synthesis and analysis:}

All statistical analyses were performed using Review Manager (RevMan) [Computer program]. Version 5.3. Copenhagen: The Nordic Cochrane Centre, The Cochrane Collaboration, 2014. We calculated the Hazards Ratio (HR) with $95 \%$ Confidence Intervals (CI) for each outcome in each study using fixed model. We choose the fixed effects model because no heterogeneity between the pooled studies was observed; $p>0.10$ and $\mathrm{I}^{2}=$ $0 \%$. Heterogeneity was calculated by Cochran Qtest and Higgins I-squared statistics $\left(\mathrm{I}^{2}\right)$ [24].

Patient involvement. No patients were involved in any step of designing the review.

\section{Results}

Study selection and baseline characteristics, Fig. (1):

Twelve studies, published from 2009-2017, fulfilled the eligibility criteria and provided the data to be integrated in systematic review. Summaries of the characteristics of the included studies were illustrated in (Table 1). Four studies investigated SREBP1 expression in HCC and corresponding non-tumor tissue (adjacent non-tumor or normal liver tissues). Six studies reported the expression of FASN. Also, SCD1 expression was included in six studies. The quality of the included studies varied from (range from 5-10) and therefore, data could be assessed at an acceptable quality level, (Table 1). 
Table (1): Main characteristics of studies included in the review.

\begin{tabular}{|c|c|c|c|c|c|c|c|c|c|}
\hline $\begin{array}{l}\text { Reference } \\
\text { (year) }\end{array}$ & Target & $\begin{array}{l}\text { Detection } \\
\text { method }\end{array}$ & $\begin{array}{l}\text { Cases } \\
\text { no (tumor/ } \\
\text { non) }\end{array}$ & $\begin{array}{c}\text { Non- } \\
\text { tumor liver } \\
\text { (cirrhosis/No) }\end{array}$ & Etiology & $\begin{array}{c}\text { Stage } \\
(\mathrm{I}+\mathrm{II} / \\
\text { III + IV })\end{array}$ & $\begin{array}{c}\text { Grade } \\
(\mathrm{I}+\mathrm{II} / \\
\text { III + IV) }\end{array}$ & $\begin{array}{l}\text { Type of } \\
\text { study }\end{array}$ & $\begin{array}{l}\text { Qualuity } \\
\text { score }\end{array}$ \\
\hline $\begin{array}{l}\text { • Yahagi, N } \\
\text { (2005) [34] }\end{array}$ & FASN & $\mathrm{IHC}$ & $10 / 10$ & $7 / 3$ & $\begin{array}{l}6 \mathrm{HCV} / 2 \mathrm{HBV} / \\
2 \mathrm{NON}\end{array}$ & NM & $8 / / 2$ & Case control & 5 \\
\hline $\begin{array}{l}\text { - Yamashita, T. } \\
\text { (2009) [35] }\end{array}$ & $\begin{array}{l}\text { SREBP1 } \\
\text { SCD1 } \\
\text { FASN } \\
\text { SREBP1 }\end{array}$ & $\begin{array}{l}\text { qRT-PCR } \\
\text { qRT-PCR } \\
\text { qRT-PCR } \\
\text { IHC }\end{array}$ & $\begin{array}{l}20 / 20 / 4 \\
54\end{array}$ & NM & $12 \mathrm{HCV} / 8 \mathrm{HBV}$ & $\begin{array}{l}\text { NM } \\
45 / 9\end{array}$ & $\begin{array}{l}\mathrm{NM} \\
\mathrm{NM}\end{array}$ & Case control & 6 \\
\hline $\begin{array}{l}\text { - Budhu, A. } \\
\text { (2013) [36] } \\
\text { LCI testing set } \\
\text { LEC validation } \\
\text { set }\end{array}$ & SCD1 & $\begin{array}{l}\text { GENTIC } \\
\text { GENTIC }\end{array}$ & $\begin{array}{l}217 \\
139\end{array}$ & $\begin{array}{l}194 / 18 \\
48 / 65\end{array}$ & $\begin{array}{l}191 \mathrm{HBV} \\
58 \mathrm{HBV}\end{array}$ & $\begin{array}{l}157 / 44 \\
\mathrm{NM}\end{array}$ & $\begin{array}{l}\mathrm{NM} \\
\mathrm{NM}\end{array}$ & Cohort & 10 \\
\hline $\begin{array}{l}\text { - Bansal, S. } \\
\text { (2014) [37] }\end{array}$ & SCD1 & IHC & $64 / 10$ & NM & NM & NM & $56 / 8$ & Case control & 8 \\
\hline $\begin{array}{l}\text { • Hao, Q. } \\
\text { (2014] [29] }\end{array}$ & FASN & $\mathrm{IHC}$ & $20 / 20$ & NM & NM & NM & NM & Case control & 6 \\
\hline $\begin{array}{l}\text { • Huang, G. } \\
\text { (2014) [38] }\end{array}$ & SCD1 & $\begin{array}{l}\text { IHC } \\
\text { qRT-PCR }\end{array}$ & $\begin{array}{l}52 / 45 \\
17 / 17\end{array}$ & $\begin{array}{l}28 / 24 \\
\mathrm{NM}\end{array}$ & $\begin{array}{l}39 \mathrm{HBV} \\
\mathrm{NM}\end{array}$ & NM & NM & Case control & 7 \\
\hline $\begin{array}{l}\text { - Li, C. (2014) } \\
{\left[^{\mathbf{2 7}}\right]}\end{array}$ & SREBP1 & $\begin{array}{l}\text { qRT-PCR } \\
\text { IHC }\end{array}$ & $47 / 47$ & $38 / 9$ & $39 \mathrm{HBV}$ & $40 / 12$ & $46 / 6$ & Case control & 7 \\
\hline $\begin{array}{l}\cdot \mathrm{Li}, \mathrm{J} .(2015) \\
\quad[30]\end{array}$ & $\begin{array}{l}\text { FASN } \\
\text { SREBP1 }\end{array}$ & $\begin{array}{l}\text { IHC } \\
\text { IHC }\end{array}$ & 76 & NM & NM & NM & NM & Case control & 5 \\
\hline $\begin{array}{l}\text { • Li, L. (2016) } \\
\text { [39] }\end{array}$ & FASN & IHC & 88 & $60 / 22$ & $\begin{array}{l}25 \mathrm{HCV} / 40 \mathrm{HBV} / \\
11 \mathrm{Non}-t u m o r\end{array}$ & $28 / 19$ & $18 / 29$ & Case control & 5 \\
\hline $\begin{array}{c}\text { - Gaggini, M. } \\
\text { (2017) [28] }\end{array}$ & $\begin{array}{l}\text { SCD1 } \\
\text { SREBP1 }\end{array}$ & $\begin{array}{l}\text { qRT-PCR } \\
\text { qRT-PCR }\end{array}$ & $18 / 18$ & $12 / 6 /$ & $18 \mathrm{HCV}$ & NM & NM & Case control & 8 \\
\hline $\begin{array}{l}\text { - Gong, J } \\
\text { (2017) [40] }\end{array}$ & FASN & IHC & $70 / 70$ & NM & NM & NM & $51 / 27$ & Case control & 6 \\
\hline $\begin{array}{l}\cdot \text { Ma, M. } \\
\quad(2017) \text { [32] }\end{array}$ & SCD1 & $\begin{array}{l}\text { qRT-PCR } \\
\text { IHC }\end{array}$ & $\begin{array}{l}70 / 70 \\
37 / 37\end{array}$ & $\begin{array}{l}\text { NM } \\
\text { NM }\end{array}$ & $\begin{array}{l}\text { NM } \\
\text { NM }\end{array}$ & $\begin{array}{l}\mathrm{NM} \\
\mathrm{NM}\end{array}$ & $\begin{array}{l}\text { NM } \\
\text { NM }\end{array}$ & Case control & 6 \\
\hline $\begin{array}{ll}\text { SREBP1 } & \text { : Sterol } \\
\text { FASN } & \text { : Fatty } \\
\text { SCD1 } & \text { : Stearo } \\
\text { qRT-PCR } & \text { : Quant }\end{array}$ & $\begin{array}{l}\text { Regulatory } \\
\text { Acid Synth } \\
\text { byl-CoA De } \\
\text { titative Real }\end{array}$ & $\begin{array}{l}\text { saturase1. } \\
\text { Time-Polym }\end{array}$ & $\begin{array}{l}\text { ding Proteins. } \\
\text { terase Chain R }\end{array}$ & ction. & $\begin{array}{l}\mathrm{IHC}: \mathrm{Im} \\
\mathrm{NM}: \mathrm{No} \\
\mathrm{HCV}: \mathrm{He} \\
\mathrm{HBV}: \mathrm{He}\end{array}$ & $\begin{array}{l}\text { Inohistoc } \\
\text { Mentionec } \\
\text { titis C Vi } \\
\text { titis B Vi }\end{array}$ & mistry. & & \\
\hline
\end{tabular}

Progressive role of lipogenic pathway on HCC:

Comparison of SREBPl expression in HCC and non-HCC tissues:

SREBP1 protein expression was upregulated in HCC tissues with the mean percent of expression was $67.4 \%$. Data obtained from studies showed high SREBP1 mRNA expression in HCC tissues in comparison with normal liver tissues $(p=0.005)$ and matched non-tumor tissues $(p=0.004)$. However, one study reports that there was not any significant difference between $\mathrm{HCC}$ and normal liver tissue regarding SREBP1 mRNA expression $(p=0.10)$.

Comparison of FASN expression in HCC and non-HCC tissues:

Expression of FASN in HCC cases was variable in the available three studies with the percent of expression was $100 \%, 64.5 \%$ and $81.8 \%$. FASN expression was significantly high in HCC tissues in comparison with normal liver tissue $(p=0.009)$ and the matched adjacent non-tumor tissue $(p<0.05)$. 
Table (2): SREBP1, FASN and SCD1 expression levels with respect with available clinicopathological data and patients' outcome.

\begin{tabular}{|c|c|c|c|c|c|c|c|c|c|}
\hline $\begin{array}{l}\text { Reference } \\
\text { (year) }\end{array}$ & Target & $\begin{array}{l}\text { Detection } \\
\text { method }\end{array}$ & $\begin{array}{c}\text { Cases no } \\
\text { (tumor/ } \\
\text { non) }\end{array}$ & $\begin{array}{c}\text { (Tumor/ } \\
\text { non) } \\
p \text {-value }\end{array}$ & $\begin{array}{l}\text { Type of tissue } \\
\text { control }\end{array}$ & $\begin{array}{l}\text { Cut-off } \\
\text { value }\end{array}$ & $\begin{array}{c}\text { OS HR } \\
(95 \% \mathrm{CI})\end{array}$ & $\begin{array}{c}\text { OS } \\
p \text {-value }\end{array}$ & $\begin{array}{c}\text { DFS } \\
\boldsymbol{p} \text {-value }\end{array}$ \\
\hline $\begin{array}{l}\cdot \text { Yahagi, N } \\
\text { (2005) [34] }\end{array}$ & FASN & IHC & $10 / 10$ & $\mathrm{NM}$ & $\begin{array}{l}\text { Tumor/ } \\
\text { Adjacent }\end{array}$ & Low/high & $\mathrm{NM}$ & $\mathrm{NM}$ & $\mathrm{NM}$ \\
\hline \multirow[t]{2}{*}{$\begin{array}{l}\text { - Yamashita, T. } \\
\text { (2009) [35] }\end{array}$} & $\begin{array}{l}\text { SREBP1 } \\
\text { SCD } \\
\text { FASN }\end{array}$ & $\begin{array}{l}\text { qRT-PCR } \\
\text { qRT-PCR } \\
\text { qRT-PCR }\end{array}$ & $20 / 20 / 4$ & $\begin{array}{l}0.005 \\
<0.001 \\
0.009\end{array}$ & $\begin{array}{l}\text { Tumor/ } \\
\text { Adjacent/ } \\
\text { Normal }\end{array}$ & NM & $\mathrm{NM}$ & NM & NM \\
\hline & SREBP1 & $\mathrm{IHC}$ & 54 & NM & $\mathrm{NM}$ & $\begin{array}{l}\text { Negative/ } \\
\text { low/high }\end{array}$ & $\begin{array}{l}3.7(1.0- \\
13.7)\end{array}$ & 0.05 & $\mathrm{NM}$ \\
\hline $\begin{array}{l}\text { - Budhu, A. } \\
\text { (2013) [36] }\end{array}$ & \multirow[t]{2}{*}{ SCD } & GENTIC & 217 & $\mathrm{NM}$ & NM & Low/high & $\begin{array}{l}1.78 \\
(1.18-2.69)\end{array}$ & 0.01 & 0.049 \\
\hline $\begin{array}{l}\text { LCI testing set } \\
\text { LEC validation } \\
\text { set }\end{array}$ & & GENTIC & 139 & NM & NM & Low/high & $\begin{array}{l}2.36 \\
(1.38-4.06)\end{array}$ & 0.002 & 0.041 \\
\hline $\begin{array}{l}\text { - Bansal, S. } \\
\text { (2014) [37] }\end{array}$ & SCD & IHC & $64 / 10$ & $<0.001$ & $\begin{array}{l}\text { Tumor/ } \\
\text { Normal }\end{array}$ & $\begin{array}{l}0,1,2,3 \\
\text { score system }\end{array}$ & NM & NM & $\mathrm{NM}$ \\
\hline $\begin{array}{l}\text { • Hao, Q. } \\
\text { (2014] [29] }\end{array}$ & FASN & IHC & $20 / 20$ & $<0.05$ & $\begin{array}{l}\text { Tumor/ } \\
\text { Adjacent }\end{array}$ & $\begin{array}{l}\text { Negative/ } \\
\text { positive }\end{array}$ & NM & NM & NM \\
\hline \multirow[t]{2}{*}{$\begin{array}{l}\text { • Huang, G. } \\
\text { (2014) [38] }\end{array}$} & \multirow[t]{2}{*}{ SCD } & IHC & $52 / 45$ & $<0.05$ & \multirow[t]{2}{*}{$\begin{array}{l}\text { Tumor/ } \\
\text { Adjacent }\end{array}$} & $\begin{array}{l}\text { Negative (0-4)/ } \\
\text { Positive (5-9) }\end{array}$ & NM & 0.05 & NM \\
\hline & & qRT-PCR & $17 / 17$ & $<0.05$ & & NM & $\mathrm{NM}$ & NM & NM \\
\hline $\begin{array}{l}\text { - Li, C. (2014) } \\
\quad[27]\end{array}$ & SREBP1 & $\begin{array}{l}\text { qRT-PCR } \\
\text { IHC }\end{array}$ & $47 / 47$ & $\begin{array}{l}0.004 \\
<0.001\end{array}$ & $\begin{array}{l}\text { Tumor/ } \\
\text { Adjacent }\end{array}$ & $\begin{array}{l}\text { Negative/ } \\
\text { positive }\end{array}$ & $\begin{array}{l}2.976 \\
(1.109-7.987)\end{array}$ & 0.03 & 0.03 \\
\hline \multirow[t]{2}{*}{$\begin{array}{l}\cdot \text { Li, J. (2015) } \\
{[\text { [30] }}\end{array}$} & FASN & IHC & \multirow[t]{2}{*}{76} & NM & \multirow[t]{2}{*}{ NM } & $\begin{array}{l}\text { Negative/mild/ } \\
\text { Moderate/high }\end{array}$ & $\mathrm{NM}$ & NM & NM \\
\hline & SREBP1 & IHC & & NM & & $\begin{array}{l}\text { Negative/mild } \\
\text { Moderate/high }\end{array}$ & & & \\
\hline $\begin{array}{l}\text { - Li, L. (2016) } \\
\text { [39] }\end{array}$ & FASN & IHC & 88 & NM & NM & $\begin{array}{l}\text { Negative/ } \\
\text { positive }\end{array}$ & $\mathrm{NM}$ & NM & NM \\
\hline $\begin{array}{l}\text { - Gaggini, M. } \\
\text { (2017) [28] }\end{array}$ & $\begin{array}{l}\text { SCD } \\
\text { SREBP1 }\end{array}$ & $\begin{array}{l}\text { qRT-PCR } \\
\text { qRT-PCR }\end{array}$ & $18 / 18$ & $\begin{array}{l}0.015 \\
0.1\end{array}$ & $\begin{array}{l}\text { Tumor/ } \\
\text { Normal }\end{array}$ & NM & NM & NM & $\mathrm{NM}$ \\
\hline $\begin{array}{l}\text { - Gong, J } \\
\text { (2017) [40] }\end{array}$ & FASN & IHC & $70 / 70$ & $<0.05$ & $\begin{array}{l}\text { Tumor/ } \\
\text { Adjacent }\end{array}$ & H score & NM & NM & NM \\
\hline \multirow[t]{2}{*}{$\begin{array}{l}\text { • Ma, M. } \\
\text { (2017) [32] }\end{array}$} & \multirow[t]{2}{*}{ SCD } & qRT-PCR & $70 / 70$ & NM & $\begin{array}{l}\text { Tumor/ } \\
\text { Adjacent }\end{array}$ & Low/high & NM & NM & 0.01 \\
\hline & & IHC & $37 / 37$ & $<0.001$ & $\begin{array}{l}\text { Tumor/ } \\
\text { Adjacent }\end{array}$ & NM & NM & NM & NM \\
\hline $\begin{array}{ll}\text { SREBP1 } & \text { : Sterol } \\
\text { FASN } & \text { : Fatty } \\
\text { SCD1 } & \text { : Stearo } \\
\text { qRT-PCR : Quanti }\end{array}$ & $\begin{array}{l}\text { Regulatory } \\
\text { Acid Synthas } \\
\text { yl-CoA Des } \\
\text { itative Real }\end{array}$ & $\begin{array}{l}\text { turase1. } \\
\text { Time-Polym }\end{array}$ & ing Proteins. & action. & & $\begin{array}{l}\text { IC : Immunohistoch } \\
M \text { : Not Mentioned } \\
S \quad: \text { Overall Surviva } \\
\text { FS : Disease-Free S }\end{array}$ & $\begin{array}{l}\text { emistry. } \\
\text { urvival. }\end{array}$ & & \\
\hline
\end{tabular}

Comparison of SCDI expression in $\mathrm{HCC}$ and non-HCC tissues:

SCD1 is expressed in $60 \%$ and $78.8 \%$ of $\mathrm{HCC}$ cases. Studies revealed overexpression of SCD1 in HCC tissue when compared with normal liver tissue ( $p<0.001$ and $p=0.015)$ and matched nontumor tissue $(p<0.001$ and $p<0.005)$. Moreover, SCD 1 protein expression was significantly higher in grade $3 \mathrm{HCC}$ when compared with normal liver tissue (2.6 \pm 0.5 versus $0.2 \pm 0.4)$.

\section{Correlation between SREBP1, FASN and SCD1 expressions:}

SREBP1 expression was positively correlated with FASN and SCD expressions ( $r=0.74, p<0.001$ and $r=0.82, p<0.001$, respectively). Similarly, there was a positive correlation between the expression of FASN and SCD in HCC cases $(p<0.001)$. However, one study revealed no significant association between SREBP1 and FASN expression in HCC cases. 


\section{Prognostic role of lipogenic pathway:}

Three studies investigated the correlation of either SREBP 1 and SCD 1 with the available histopathological data as a predictor of prognosis and outcome. High SREBP1 expression in HCC tissues was significantly associated with large tumor size $(p=0.005, r=0.413)$, poor histological grade $(p=$ $0.006, r=0.400)$ and high pathologic stage $(p=$ $0.010, r=0.378)$. Similarly, SCD 1 protein expression was significantly higher in grade $3 \mathrm{HCC}$ compared with grade $1 \mathrm{HCC}(2.6 \pm 0.5$ versus $1.7 \pm$ $0.3)$. However, one study reported no significant association between high SCD1 expression and the poor clinicopathological parameters.

Overall Survival (OS) and Disease-Free Survival (DFS):

OS and DFS is the most reliable indicator for the prognostic and clinical outcome. Data were summarized in (Table 2).

Using a fixed model effect to analyze the association of SREBP1 expression and OS data from two studies showing no significant heterogeneity $\left(p=0.84 \% ; \mathrm{I}^{2}=0 \%\right)$, HCC cases with high SREBP 1 expression was associated with shorter $\mathrm{OS}(\mathrm{HR}=$ 23.09 ; $95 \% \mathrm{CI}=1.21-438.67 ; p=0.04$ ), Fig. (2A). In addition, one study reported shorter DFS time in SREBP1 positive HCC group when compared with negative group ( 8 months versus 20$)(\mathrm{HR}=$ 2.327 ; 95\% CI=1.093-4.955; $p=0.029$ ).

Four studies investigated the association of SCD1 and OS and/or DFS in HCC. OS data were

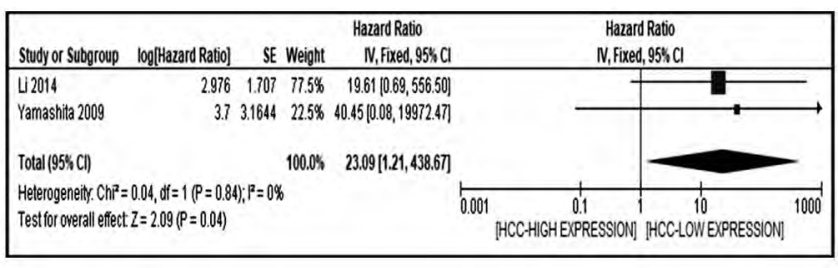

(A) available from two cohort studies. High expression of SCD1 in HCC was associated with short OS time $(\mathrm{HR}=6.82 ; 95 \% \mathrm{CI}=3.53-13.16 ; p<0.001)$, Fig. (2B). No heterogeneity between the studies was observed $\left(p=0.46 ; \mathrm{I}^{2}=0 \%\right)$. Therefore, we used fixed effect model to calculate HR. Similarly, one study revealed high SCD1 expression was associated with short OS in HCC patients ( $p=0.048$ ). Additionally, high SCD1 expression was associated with short DFS time $(p=0.008, p=0.048$ and $p=$ $0.004)$.

Studies identified through database searching $(n=389)$ PubMed $(\mathrm{n}=289)$

Google Scholar $(\mathrm{n}=100)$

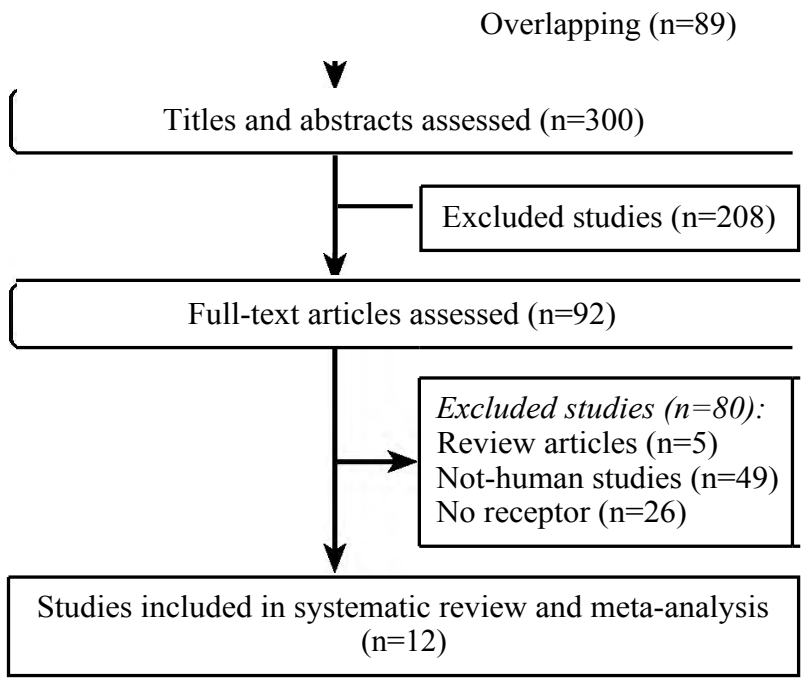

Fig. (1): Flow diagram of the study review process for the systematic review and meta-analysis.

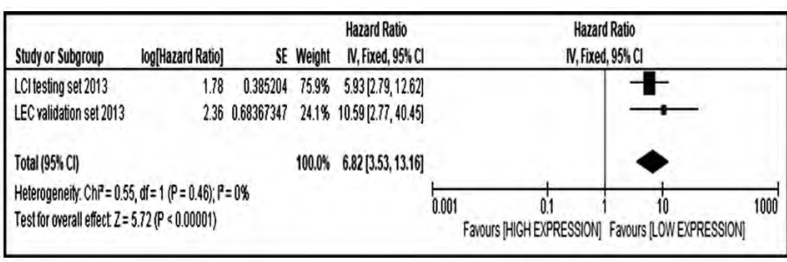

(B)

Fig. (2): Forrest plots of Overall Survival (OS) pooled data in correlations of SREBP1 and SCD1 expression in HCC cases. (A) Comparison between high and low expression of SREBP 1 in HCC. (B) Comparison between high and low expression of SCD1 in HCC cases.

\section{Discussion}

Hepatocellular carcinoma is a common cancer with a high mortality rate. Management of HCC remains challenging due to late diagnosis and the presence of accompanying liver dysfunction [4] Emerging evidence supports the importance of cancer metabolism in providing a background to accelerate the development and progression of HCC [25].
Lipogenic pathway is one of the commonly altered metabolic pathways and its alteration plays a dramatic role in progression, invasion and prognosis of various human cancers [26]. Activation of lipogenic pathway is regulated by SREBP1 family.

In this review, we extracted data from 12 studies that enrolled 1031 patients with HCC, chronic hepatitis and normal subjects. Majority of included $\mathrm{HCC}$ cases were related to HBV infection with 
few cases were related to $\mathrm{HCV}$ infection or negative viral etiology.

This review reported that SREBP1 was upregulated in $\mathrm{HCC}$ tissues and its expression was higher in $\mathrm{HCC}$ compared with non-HCC tissues (both adjacent non-tumor tissues and normal control). Indeed, the results of protein expression (IHC) is compatible with the RNA expression (qRT-PCR) [27]. However, Gaggini, et al., reported no significant difference in SREBP1 expression between HCC and normal liver tissue [28]. This could be explained by relative small sample size. Similarly, FASN was highly expressed in HCC in comparison with non-HCC tissues. However, studies showed some variability in the percentage of FASN expression [29-31]. This heterogeneity could be explained by the difference in cut-off points used and small number of cases included in some studies [29]. All studies included in this review revealed increased SCD1 expression in HCC cases and its expression was significantly different when compared with the adjacent non-tumor tissues or normal liver tissue.

In this review, we found that there was a positive correlation between SREBP1, FASN and SCD1 expression in HCC cases. Therefore, inhibition of one protein may lead to inactivation of others and subsequently downregulation of the pathway. However, a small study revealed no association between SREBP1 and FASN expression.

We found that activation of lipogenic pathway indicates poor prognosis of HCC cases. Based on histopathological data, SREBP1 high expression was associated with large tumor size, poor grade and advanced stage which indicated poor prognostic features. Moreover, evidence data showed that overexpression of SREBP1 was correlated with short survival time of HCC patients. Similarly, high expression of SREBP1 target genes, FASN and SCD1, was strongly associated with short OS and DFS of HCC patients. Some in-vitro studies have also reported similar results, in which high expression of SREBP1 and down streaming target gene for example FASN facilitated tumor invasion and metastasis in different HCC cell lines [27,29].

Interestingly, we could not report significant heterogeneity regarding the poor prognostic role of SREBP1, FASN and SCD1 despite different HCC etiology and the variable methods of detection and assessment including IHC, qRT-PCR and genomic profiling.

This is the first systematic review and metaanalysis to specifically address the expression of
SREBP1, FASN and SCD1 in HCC patients and the impact of their activation in HCC prognosis and patients' survival. Our results indicate that expression of these markers is upregulated in HCC and high expression is associated with poor OS and DFS.

Several in-vitro studies have shown that inhibition of SREBP1, FASN and SCD1 can induce apoptosis of tumor cells and decrease invasion and metastasis in different human cancers [21,32]. Moreover, the use of statins, cholesterol lowering drugs, has been postulated to have a direct role in prevention and treatment of cancer through inhibition of lipogenic pathway [33]. Thus, establishing the role of altered lipid metabolism in HCC can be a potential target for prevention and treatment of HCC in high risk patients.

\section{Limitations:}

This review has some limitations; first, small number of studies investigated the expression of SREBP1, FASN and SCD1 on human HCC tissues. Second, moderate quality of some studies included in this review may affect the reliability of the results. Third, there was shortage in the available clinicopathological data to compare the expression with the pathological features and patients' outcome. Finally, no prospective studies were available of this meta-analysis.

\section{Conclusion:}

This review suggests that high expression of SREBP1, FASN and SCD1 plays a role in HCC development and their high expression predicts poor prognosis in HCC patients. However, further high quality and large-scale studies are required to confirm the results. This will help in providing accurate prognostic information and in establishing new therapeutic targets.

\section{Conflict of interest:}

The authors declare no conflict of interest.

\section{References}

1- HASHIM D., BOFFETTA P., La VECCHIA C., ROTA M., BERTUCCIO P., MALVEZZI M., et al.: The global decrease in cancer mortality: Trends and disparities. Annals of oncology: Official Journal of the European Society for Medical Oncology, May, 27 (5): 926-33, 2016.

2- TORRE L.A., BRAY F., SIEGEL R.L., FERLAY J., LORTET-TIEULENT J. and JEMAL A.: Global cancer statistics, 2012. CA: A Cancer Journal for Clinicians, Mar., 65 (2): 87-108, 2015.

3- EL-SERAG H.B. and RUDOLPH K.L.: Hepatocellular carcinoma: Epidemiology and molecular carcinogenesis. Gastroenterology, Jun., 132 (7): 2557-76, 2007. 
4- GBOLAHAN O.B., SCHACHT M.A., BECKLEY E.W., LaROCHE T.P., O'NEIL B.H. and PYKO M.: Locoregional and systemic therapy for hepatocellular carcinoma. Journal of Gastrointestinal Oncology, Apr., 8 (2): 215 28, 2017.

5- DENG G.L., ZENG S. and SHEN H.: Chemotherapy and target therapy for hepatocellular carcinoma: New advances and challenges. World Journal of Hepatology, Apr. 18; 7 (5): 787-98, 2015.

6- GISH R.G., PORTA C., LAZAR L., RUFF P., FELD R., CROITORU A., et al.: Phase III randomized controlled trial comparing the survival of patients with unresectable hepatocellular carcinoma treated with nolatrexed or doxorubicin. Journal of Clinical Oncology: Official Journal of the American Society of Clinical Oncology, Jul. 20; 25 (21): 3069-75, 2007.

7- ZAIDI N., LUPIEN L., KUEMMERLE N.B., KINLAW W.B., SWINNEN J.V. and SMANS K.: Lipogenesis and lipolysis: The pathways exploited by the cancer cells to acquire fatty acids. Progress in lipid research, Oct., 52 (4): 585-9, 2013.

8- ZHAO X., FENG D., WANG Q., ABDULlA A., XIE X.J., ZHOU J., et al.: Regulation of lipogenesis by cyclindependent kinase 8-mediated control of SREBP-1. The Journal of Clinical Investigation, Jul., 122 (7): 2417. 27,2012 .

9- HUA X., WU J., GOLDSTEIN J.L., BROWN M.S. andHOBBS H.H.: Structure of the human gene encoding sterol regulatory element binding protein-1 (SREBF1) and localization of SREBF1 and SREBF2 to chromosomes 17 p11.2 and 22q13. Genomics. Feb. 10, 25 (3): 667-73, 1995.

10- DAEMEN S., KUTMON M. and EVELO C.T.: A pathway approach to investigate the function and regulation of SREBPs. Genes \& nutrition, May, 8 (3): 289-300, 2013.

11- NIE L.Y., LU Q.T., LI W.H., YANG N., DONGOL S., ZHANG X., et al.: Sterol regulatory element-binding protein 1 is required for ovarian tumor growth. Oncology reports, Sep., 30 (3): 1346-54, 2013.

12- SUN Y., HE W., LUO M., ZHOU Y., CHANG G., REN W., et al.: SREBP1 regulates tumorigenesis and prognosis of pancreatic cancer through targeting lipid metabolism. Tumour biology: The Journal of the International Society for Oncodevelopmental Biology and Medicine, Jun., 36 (6): 4133-41, 2015.

13- BAO J., ZHU L., ZHU Q., SU J., LIU M. and HUANG W.: SREBP-1 is an independent prognostic marker and promotes invasion and migration in breast cancer. Oncology letters, Oct., 12 (4): 2409-16, 2016.

14- SIQINGAOWA, SEKAR S., GOPALAKRISHNAN V. and TAGHIBIGLOU C.: Sterol regulatory element-binding protein 1 inhibitors decrease pancreatic cancer cell viability and proliferation. Biochemical and Biophysical Research Communications, Jun. 17, 488 (1): 136-40, 2017.

15- CAI Y., WANG J., ZHANG L., WU D., YU D., TIAN X., et al.: Expressions of fatty acid synthase and HER2 are correlated with poor prognosis of ovarian cancer. Medical oncology (Northwood, London, England), Jan., 32 (1): 391,2015 .

16- COROMINAS-FAJA B., VELLON L., CUYAS E., BUXO M., MARTIN-CASTILLO B., SERRA D., et al.: Clinical and therapeutic relevance of the metabolic oncogene fatty acid synthase in HER2+ breast cancer. Histology and histopathology, Jul., 32 (7): 687-98, 2017.

17- HOLDER A.M., GONZALEZ-ANGULO A.M., CHEN H., AKCAKANAT A., DO K.A., SYMMANS W.F., et al.: High stearoyl-CoA desaturase 1 expression is associated with shorter survival in breast cancer patients. Breast cancer research and treatment, 12/04, 137 (1): 319-27, 2013.

18- WANG J., XU Y., ZHU L., ZOU Y., KONG W., DONG B., et al.: High Expression of Stearoyl-CoA Desaturase 1 Predicts Poor Prognosis in Patients with Clear-Cell Renal Cell Carcinoma. PloS one, 11 (11): e0166231, 2016.

19- GUO D., BELL E.H., MISCHEL P. and CHAKRAVARTI A.: Targeting SREBP-1-driven lipid metabolism to treat cancer. Current Pharmaceutical Design, 20 (15): 261926, 2014.

20- IMAMURA K., TOMITA N., KAWAKITA Y., ITO Y., ONO K., NII N., et al.: Discovery of Novel and Potent Stearoyl Coenzyme A Desaturase 1 (SCD1) Inhibitors as Anticancer Agents. Bioorganic \& Medicinal Chemistry, Jul. 15, 25 (14): 3768-79, 2017.

21- MENENDEZ J.A. and LUPU R.: Fatty acid synthase (FASN) as a therapeutic target in breast cancer. Expert opinion on therapeutic targets, Nov., 21 (11): 1001-16, 2017.

22- MOHER D., LIBERATI A., TETZLAFF J. and ALTMAN D.G.: Preferred reporting items for systematic reviews and meta-analyses: The PRISMA statement. Annals of Internal Medicine, Aug. 18, 151 (4): 264-9, w64, 2009.

23- STANG A.: Critical evaluation of the Newcastle-Ottawa scale for the assessment of the quality of nonrandomized studies in meta-analyses. European Journal of Epidemiology, Sep., 25 (9): 603-5, 2010.

24- DerSIMONIAN R. and KACKER R.: Random-effects model for meta-analysis of clinical trials: An update. Contemp. Clin. Trials., Feb., 28 (2): 105-14, 2007.

25- HO D.W.H., LO R.C.L., CHAN L.K. and NG I.O.L.: Molecular Pathogenesis of Hepatocellular Carcinoma. Liver Cancer, Oct., 5 (4): 290-302, 2016.

26- FURUTA E., OKUDA H., KOBAYASHI A. and WATABE K.: Metabolic genes in cancer: Their roles in tumor progression and clinical implications. Biochimica et biophysica acta, Apr., 1805 (2): 141-52, 2010.

27- LI C., YANG W., ZHANG J., ZHENG X., YAO Y., TU K., et al.: SREBP-1 has a prognostic role and contributes to invasion and metastasis in human hepatocellular carcinoma. International Journal of Molecular Sciences, Apr. 25, 15 (5): 7124-38, 2014.

28- GAGGINI M., CABIATI M., DEL TURCO S., NAVARRA T., De SIMONE P., FILIPPONI F., et al.: Increased FNDC5/Irisin expression in human hepatocellular carcinoma. Peptides, Feb., 88: 62-6, 2017.

29- HAO Q., LI T., ZHANG X., GAO P., QIAO P., LI S., et al.: Expression and roles of fatty acid synthase in hepatocellular carcinoma. Oncology reports, Dec., 32 (6): 2471 6, 2014.

30- LI J., HUANG Q., LONG X., ZHANG J., HUANG X., AA J., et al.: CD147 reprograms fatty acid metabolism 
in hepatocellular carcinoma cells through Akt/mTOR/ SREBP1c and P38/PPARalpha pathways. Journal of Hepatology, Dec., 63 (6): 1378-89, 2015.

31- LI L., PILO G.M., LI X., CIGLIANO A., LATTE G., CHE L., et al.: Inactivation of fatty acid synthase impairs hepatocarcinogenesis driven by AKT in mice and humans. Journal of Hepatology, Feb., 64 (2): 333-41, 2016.

32- MA M.K.F., LAU E.Y.T., LEUNG D.H.W., LO J., HO N.P.Y., CHENG L.K.W., et al.: Stearoyl-CoA desaturase regulates sorafenib resistance via modulation of ER stressinduced differentiation. Journal of Hepatology, Nov., 67 (5): 979-90, 2017.

33- HINDLER K., CLEELAND C.S., RIVERA E. and COLLARD C.D.: The role of statins in cancer therapy. Oncologist, Mar., 11 (3): 306-15, 2006.

34- YAHAGI N., SHIMANO H., HASEGAWA K., OHASHI K., MATSUZAKA T., NAJIMA Y., et al.: Co-ordinate activation of lipogenic enzymes in hepatocellular carcinoma. European Journal of Cancer (Oxford, England: 1990). Jun., 41 (9): 1316-22, 2005.

35- YAMASHITA T., HONDA M., TAKATORI H., NISHINO R., MINATO H., TAKAMURA H., et al.: Activation of lipogenic pathway correlates with cell proliferation and poor prognosis in hepatocellular carcinoma. Journal of Hepatology, Jan., 50 (1): 100-10, 2009.
36- BUDHU A., ROESSLER S., ZHAO X., YU Z., FORGUES M., JI J., et al.: Integrated metabolite and gene expression profiles identify lipid biomarkers associated with progression of hepatocellular carcinoma and patient outcomes. Gastroenterology, May, 144 (5): 1066-75.e1, 2013.

37- BANSAL S., BERK M., ALKHOURI N., PARTRICK D.A., FUNG J.J. and FELDSTEIN A.: Stearoyl-CoA desaturase plays an important role in proliferation and chemoresistance in human hepatocellular carcinoma. The Journal of Surgical Research, Jan., 186 (1): 29-38, 2014.

38- HUANG G.M., JIANG Q.H., CAI C., QU M. and SHEN $\mathrm{W}$.: SCD1 negatively regulates autophagy-induced cell death in human hepatocellular carcinoma through inactivation of the AMPK signaling pathway. Cancer Lett., Mar. 28, 358 (2): 180-90, 2014.

39- LI L., CHE L., THARP K.M., PARK H.M., PILO M.G., CAO D., et al.: Differential requirement for de novo lipogenesis in cholangiocarcinoma and hepatocellular carcinoma of mice and humans. Hepatology (Baltimore, Md), Jun., 63 (6): 1900-13, 2016.

40- GONG J., SHEN S., YANG Y., QIN S., HUANG L., ZHANG $\mathrm{H}$., et al.: Inhibition of FASN suppresses migration, invasion and growth in hepatoma carcinoma cells by deregulating the HIF-1alpha/IGFBP1 pathway. International Journal of Oncology, Mar., 50 (3): 883-92, 2017.

\section{دور التغير فى مسار تكون الدهون فى سرطان الخلايا الكبدية: مراجعة منهجية وتحليل تلوى}

$$
\begin{aligned}
& \text { الهقدمة: لا يزال سرطان الكبد من أكثر أنواع السرطانات شيوعاً ومسببه للوفاه فى جميع أنحاء العالم على الرغم من التقدم فى طرق }
\end{aligned}
$$

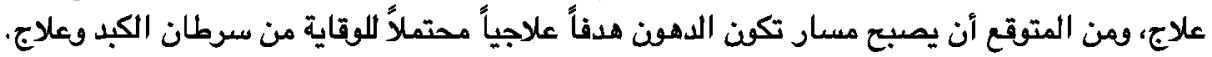

$$
\begin{aligned}
& \text { الأهداف: لذا هذا البحث يهدف إلى دراسة دود مسار تكون الدهون فى حدق وتطود سرطان الكبد. } \\
& \text { الطرق: قمنا بالبحث فى قواعد بيانات الباحثين فى بيمد وجوجل سكولر عن الدراسات ذات الصلة فى تقيّم إظهار محددات مسار الدهون }
\end{aligned}
$$

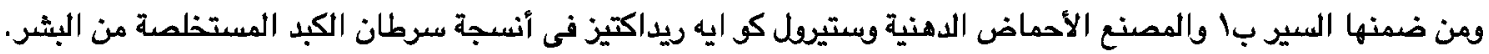

$$
\begin{aligned}
& \text { النتائج: شملت هذه المراجعة با دراسة شملت اس ـا 1 مريضاً يعانفن من سرطان الكبد المزمن أو التهاب الكبد المزمن والأشخاص }
\end{aligned}
$$

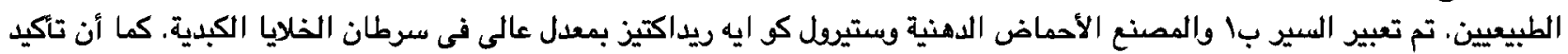

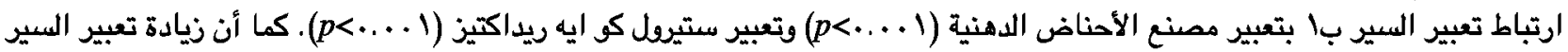

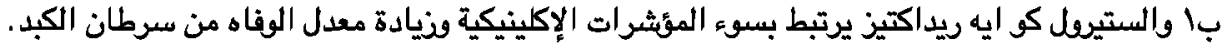

$$
\begin{aligned}
& \text { الخلاصدة: خلصنا إلى أن مسار تكون الدهوف يلعب دواً فعالاً فى حدوث وتطوف سرطان الكبد. }
\end{aligned}
$$

